\title{
UJI KUALITAS MAKANAN JAJANAN PENTOL YANG DIJUAL PEDAGANG KELILING DI LINGKUNGAN SDN BANJAREJO 2 KECAMATAN PANEKAN KABUPATEN MAGETAN
}

\author{
Insan Arif Setyawan, Djoko Windu P. Irawan, Denok Indraswati
}

\begin{abstract}
ABSTRAK
Makanan adalah kebutuhan pokok manusia yang diperlukan setiap saat dan memerlukan pengolahan yang baik dan benar agar bermanfaat bagi tubuh, adapun pengertian makanan yaitu semua substansi yang diperlukan oleh tubuh, kecuali air dan obat-obatan dan semua substansi yang digunakan untuk pengobatan.

Penelitian ini bertujuan untuk memeriksa kualitas makanan pentol ditinjau dari aspek fisik (organoleptik), kimia yaitu boraks, formalin, rhodamin-b, dan aspek mikrobiologi yaitu angka kuma, kemudian dianalisa.

Jenis penelitian adalah deskriptif, pemeriksaan sebanyak 3 kali terhadap masing-masing sampel, jenis pengambilan sampel total sampling. Analisis data dituangkan dalam bentuk tabel kemudian dinarasikan.

Hasil penelitian dari aspek fisik: warna putih pucat keabu-abuan, aroma bau khas daging dan pati, tekstur kenyal dan kasar, rasa gurih daging dan asin. Aspek kimia: 7 sampel $(77,77 \%)$ negatif boraks, 9 sampel (100\%) negatif formalin, 9 sampel $(100 \%)$ negatif rhodamin B. Aspek mikrobiologi: angka kuman 5 sampel $(55,55 \%)$ melebihi baku mutu.

Disarankan perlu diteliti lebih lanjut tentang perilaku penjaja makanan dalam melaksanakan prinsip-prinsip hygiene sanitasi makanan.

Kata Kunci : Kualitas Makanan Pentol, Pedagang Keliling
\end{abstract}

\section{PENDAHULUAN}

Makanan diperlukan untuk kehidupan karena makanan merupakan salah satu kebutuhan pokok bagi kehidupan manusia. Makanan berfungsi untuk memelihara proses tubuh dalam pertumbuhan atau perkembangan serta mengganti jaringan tubuh yang rusak, memperoleh energi untuk melakukan aktifitas sehari-hari, mengatur metabolisme dan berbagai keseimbangan air, mineral, dan cairan tubuh yang lain, juga berperan di dalam mekanisme pertahanan tubuh terhadap berbagai penyakit (Notoatmodjo, 2003).

Untuk mendapatkan makanan dan minuman yang memenuhi syarat kesehatan, perlu diadakan pengawasan terhadap higiene dan sanitasi makanan dan minuman utamanya adalah usaha yang diperuntukkan untuk umum seperti rumah sakit, restoran, rumah makan, atau pedagang kaki lima mengingat bahwa makanan dan minuman merupakan media yang potensial dalam penyebaran penyakit (Depkes RI, 2004).

Menurut Kepmenkes RI Nomor 942/Menkes/SK/VII/2003 Tentang Pedoman Persyaratan Hygiene Sanitasi Makanan Jajanan pada Bab I Ketentuan Umum Pasal 1, bahwa yang dimaksud dengan makanan jajanan adalah makanan dan minuman yang diolah oleh pengrajin makanan di tempat penjualan dan atau disajikan sebagai makanan siap santap untuk dijual bagi umum selain yang disajikan jasa boga, rumah makan/restoran, dan hotel.

Peraturan Pemerintah Nomer 28 Tahun 2004 tentang keamanan, mutu dan gizi pangan mengamanatkan bahwa pengawasan keamanan pangan harus dilakukan secara terpadu oleh pemerintah pusat dan pemerintah kabupaten/kota. Salah satu prioritas pengawasan pangan adalah pangan jajanan anak sekolah (PJAS). Hal ini dianggap penting mengingat anak sekolah merupakan cikal bakal Sumber Daya manusia (SDM) suatu negara. Pangan jajanan memegang peranan penting dalam memberikan asupan energi dan gizi bagi anak-anak usia sekolah.

$$
\text { Sejumlah survei terhadap }
$$

kejadian luar biasa (KLB) penyakit bawaan makanan yang berjangkit di seluruh dunia memperlihatkan bahwa sebagian besar kasus penyakit bawaan makanan terjadi akibat kesalahan penanganan pada saat penyiapan makanan baik di rumah, jasa katering, kantin rumah sakit, sekolah atau di pasar, dan lain-lain (WHO, 2006).

Data Dinas Kesehatan Kabupaten Magetan tahun 2014 terjadi 29 kasus KLB, yang terdiri 16 kasus KLB akibat penyakit, KLB akibat keracunan makanan 4 kasus, dan terjadi 9 KLB akibat bencana. 
Di Sekolah Dasar Negeri (SDN) Banjarejo 2 pernah terjadi keracunan makanan yang disebabkan dari makanan jajanan dan menyebabkan korban 22 siswa. SDN Banjarejo 2 adalah sekolah dasar yang terletak di Desa Banjarejo, Kecamatan Panekan, Kabupaten Magetan. Jumlah siswa keseluruhan 126 siswa. Setiap hari siswa-siswi membeli makanan jajanan yang dijajakan oleh pedagang keliling yang berjualan di lingkungan sekolah, pedagang berjumlah 6 orang terdiri dari 3 pedagang pentol, 1 pedagang tempura, 1 pedagang makanan kemasan.

Penentuan jenis makanan sebagai sampel penelitian didasarkan atas peminatan makanan jajanan yang paling diminati oleh siswa. Hasil angket diperoleh hasil makanan jajanan pentol diminati siswa dengan persentase $41,2 \% \quad$ (52 anak), tempura 29,3\% (37 anak), makanan gorengan 7,9\% (10 anak), dan jajanan kemasan 21,4 \%(27 anak). Berdasarkan hasil angket menunjukan makanan pentol memiliki peminatan tertinggi dari pada makanan lain. Hasil observasi awal terhadap makanan pentol dari aspek kualitas fisik umumnya rasanya gurih, bau khas daging, warna putih pucat keabu-abuan, tekstur kenyal, lembut, keras. Berdasarkan uji pendahuluan di laboraturium negatif boraks dan formalin. Sedangkan secara mikrobiologis mengandung angka kuman 4.400 $\mathrm{kol} / \mathrm{gram}$ yang melebihi baku mutu yaitu $1 \times 10^{5} \mathrm{kol} / \mathrm{gram}$ Peraturan Kepala Badan Pengawas Obat dan Makanan RI No. HK.00.06.1.52.4011 tentang Penetapan Batas Maksimum Cemaran Mikroba Dan Kimia Dalam Makanan.

\section{TUJUAN}

Mengetahui kualitas makanan jajanan pentol yang di jual pedagang keliling di lingkungan SDN Bajarejo 2 Kecamatan Panekan Kabupaten Magetan, yang dirinci menjadi:

1. Memeriksa kualitas makanan jajanan pentol ditinjau dari aspek fisik (organoleptik) meliputi warna, rasa, tesktur dan aroma.

2. Memeriksa kualitas makanan jajanan pentol ditinjau dari aspek kimia meliputi boraks, formalin, rhodamin B.

3. Memeriksa kualitas makanan jajanan pentol ditinjau dari aspek mikrobiologis yaitu angka kuman.

4. Menganalisa kualitas makanan jajanan pentol ditinjau dari fisik, kimia dan mikrobiologi.

METODE PENELITIAN
Penelitian ini merupakan penelitian deskriptif, didesain berdasarkan pendekatan cross sectional, data yang dikumpulkan pada waktu yang bersamaan dan variabel yang diteliti diukur hanya satu kali (Sastroasmoro dan Ismail, 2002).

Sampel diambil dimana para pedagang keliling berjualan makanan jajanan pentol yaitu di lingkungan SDN Banjarejo 2 Desa Banjarejo Kecamatan Panekan Kabupaten Magetan. Pemeriksaan sampel di Laboratorium Prodi D-III Kesehatan Lingkungan Kampus Magetan dan Laboratorium Kesehatan Daerah Kabupaten Magetan.

Waktu Penelitian : Bulan Pebruari sampai Juli 2015.

Populasi Penelitian: Seluruh pedagang makanan jajanan pentol sebanyak 3 pedagang pentol.

Sampel Penelitian : Makanan jajanan yang dipilih sebagai sampel adalah pentol.

Besar sampel penelitian ini yaitu sebanyak 3 sampel makanan jajanan pentol untuk pemeriksaan fisik, kimia dan mikrobiologi, dengan pengambilan sampel sebanyak 3 kali, sehingga jumlah sampel yang diambil dan diperiksa sebanyak 45 sampel.

Pengambilan sampel yaitu total sampling bahwa setiap semua anggota atau unit dari populasi sebagai sampel. Jadi semua populasi makanan jajanan pentol yang dijual pedagang keliling di lingkungan SDN Banjarejo 2 dijadikan sampel. Variabel Penelitian: kualitas fisik, kimia dan mikrobiologi Makanan Jajanan Pentol. Variabel Pengganggu: kuah, penjamah makanan, peralatan, air, alat makan, bahan makanan, penyajian, lingkungan. Pengumpulan Data dengan Angket, Observasi, Pemeriksaan Laboratorium.

\section{HASIL PENELITIAN DAN PEMBAHASAN}

1. Aspek Fisik

Pemeriksa kualitas fisik pentol digunakan metode organoleptik menggunakan panca indra meliputi rasa, tekstur, bau dan warna terhadap sampel. Kualitas fisik makanan jajanan pentol ditinjau dari aspek organoleptik.Sampel yang diperiksa berwarna putih pucat keabu-abuan. Makanan jajanan pentol yang mengandung boraks dan formalin warnanya putih pucat baik di luar maupun bagian dalamnya. Aroma sampel pentol bau daging dan pati. Pentol yang mengandung boraks dan formalin memiliki 
bau yang tidak seperti bau daging pada umumnya. Tekstur sampel pentol kenyal dan kasar. Pentol yang mengandung boraks dan formalin memiliki tekstur lebih kenyal dari pada pentol tanpa boraks dan formalin. Rasa pentol rasanya gurih daging dan asin. Pentol yang mengandung boraks dan formalin memiliki rasa getir dan sangat gurih serta beraroma sangat tajam (Khannedy Eko, 2012).

Dari pembahasan di atas makanan pentol secara organoleptik kurang layak untuk dikonsumsi.

Tabel 1. Hasil Pemeriksaan Organoleptik

\begin{tabular}{c|c|c|c|c}
\hline \multirow{2}{*}{ Sampel } & \multicolumn{4}{|c}{ Uji Organoleptik } \\
\cline { 2 - 5 } & Kenampakan & Aroma & Tekstur & Rasa \\
\hline 1 & $\begin{array}{c}\text { Putih Pucat Keabu- } \\
\text { abuan }\end{array}$ & $\begin{array}{c}\text { Bau daging dan } \\
\text { pati } \\
\text { Bau daging dan } \\
\text { pati }\end{array}$ & Kenyal dan kasar & $\begin{array}{c}\text { Gurih daging dan } \\
\text { asin }\end{array}$ \\
\hline 3 & $\begin{array}{c}\text { Putih Pucat Keabu- } \\
\text { abuan }\end{array}$ & $\begin{array}{c}\text { Kanan kasar } \\
\text { Keabu-abuan }\end{array}$ & $\begin{array}{c}\text { Gaurih daging dan } \\
\text { asin }\end{array}$ \\
\hline Rata2 & $\begin{array}{c}\text { Putih pucat keabu- } \\
\text { abuan }\end{array}$ & $\begin{array}{c}\text { Bau daging } \\
\text { dan pati }\end{array}$ & Kenyal dan kasar & $\begin{array}{c}\text { Gurih daging dan } \\
\text { asin }\end{array}$ \\
\hline
\end{tabular}

Tabel 2. Distribusi Hasil Pemeriksan Organoleptik

\begin{tabular}{c|l|c|c}
\hline No & \multicolumn{1}{|c|}{ Distribusi } & Frekuensi & Presentase \\
\hline 1 & Organoletpik Memenuhi syarat & 5 & $55.55 \%$ \\
\hline 2 & Organoleptik Tidak Memenuhi Syarat & 4 & $44.44 \%$ \\
\hline & Total & 9 & $100 \%$ \\
\hline
\end{tabular}

Berdasarkan tabel 2, makanan jajanan pentol ditinjau dari aspek organoleptik yang memenuhi syarat $5(55.55 \%)$ dan tidak memenuhi syarat 4 dengan persentase 44.44\%.

1. Hasil Pemeriksaan Aspek Kimia: Boraks Kualitas makanan pentol ditinjau dari aspek kimia: boraks

Dilihat pada hasil laboratorium pada pemeriksaan pertama diperoleh hasil semua sampel negatif boraks. Pemeriksaan ke dua terdapat 1 sampel positif boraks dan 2 sampel negatif boraks sedangkan pada pemeriksaan ke tiga terdapat 1 sampel positif boraks dan 2 negatif boraks. Pada pemeriksaan pertama, ke dua dan ke tiga diperoleh hasil rata-rata tidak terdapat kandungan boraks pada pentol dari 9 sampel ternyata 2 sampel positif boraks (22,22 \%), dan yang tidak mengandung boraks sebanyak 7 sampel $(77,77 \%)$ sedangkan batas syarat baku mutu Permenkes RI Nomor 33 tahun 2012 tentang Bahan Tambahan Makanan (BTM), pada makanan jajanan tidak diperbolehkan mengandung boraks.

Mengkonsumsi makanan berboraks dalam jumlah berlebihan akan menyebabkan gangguan otak, hati, dan ginjal. Dalam jumlah banyak, boraks menyebabkan demam, anuria, koma, pingsan, apatis, merangsang sistem saraf pusat, menimbulkan depresi, sianosis, tekanan darah turun, kerusakan ginjal, hingga kematian (Pamere Nurhidayat, 2012).

Tabel 3. Distribusi Hasil Pemeriksan Kimia Boraks

\begin{tabular}{c|l|c|c}
\hline No & \multicolumn{1}{|c|}{ Distribusi } & Frekuensi & Persentase \\
\hline 1 & Positif Boraks & 2 & $22,22 \%$ \\
\hline 2 & Negatif Boraks & 7 & $77,77 \%$ \\
\hline & Total & 9 & $100 \%$ \\
\hline
\end{tabular}

Sumber: Hasil pemeriksaan laboratorium Prodi D III Kesling Kampus Magetan, Tahun 2015

Berdasarkan tabel 3, makanan pentol ditinjau dari aspek kimia boraks sampel yang positif boraks 2 dengan persentase $22,22 \%$ dan sampel yang negatif boraks 7 dengan persentase $77,77 \%$.

2. Hasil Pemeriksaan Aspek Kimia: Formalin
Kualitas makanan pentol ditinjau dari aspek kimia: formalin.

Pada pemeriksaan pertama, ke dua dan ke tiga diperoleh hasil semua tidak terdapat kandungan formalin dengan persentase $100 \%$ sedangkan batas syarat baku mutu 
Permenkes RI Nomor 33 tahun 2012 tentang BTM, Pada makanan jajanan tidak diperbolehkan mengandung formalin.

Dari hasil laboratorium menunjukkan bahwa pentol memenuhi batas syarat baku mutu. Bahaya formalin ialah pada saat secara langsung terkonsumsi, baik itu terhirup ataupun terkena pada makanan yang dikonsumsi. Pada konsentrasi yang pekat, dampak dari formalin dapat berupa iritasi pada saluran pernafasan, reaksi alergi, pemicu kanker dan dapat pula menyebabkan kulit terbakar. Jika tertelan Formalin sebanyak $30 \mathrm{ml}$ atau 2 sendok makan, maka dapat menyebabkan kematian akibat keracunan (Mahfuzh, 2014).

Tabel 4. Distribusi hasil pemeriksan formalin

\begin{tabular}{c|l|c|c}
\hline No & \multicolumn{1}{|c|}{ Distribusi } & Frekuensi & Persentase \\
\hline 1 & Positif Formalin & 0 & $00,00 \%$ \\
\hline 2 & Negatif Formalin & 9 & $100 \%$ \\
\hline & Total & 9 & $100 \%$ \\
\hline
\end{tabular}

Sumber: Hasil pemeriksaan laboratorium Prodi D III Kesling Kampus Magetan, Tahun 2015

Berdasarkan tabel 4, makanan pentol ditinjau dari aspek kimia formalin sampel yang positif formalin 0 dengan persentase $00,00 \%$ dan negatif formalin 9 dengan persentase $100 \%$.

3. Hasil pemeriksaan Rhodamin-B

Kualitas makanan saus pentol ditinjau dari aspek kimia: Rhodamin B.

Dengan hasil pemeriksaan laboratorium diketahui bahwa 9 sampel saus pentol negatif mengandung rhodamin $\mathrm{B}$ dengan $B$ bisa memicu kanker jika di produksi tahunan (Anonim, 2011). persentase $100 \%$. Saus pentol memenuhi syarat baku mutu Permenkes RI Nomor 33 tahun 2012 tentang Bahan Tambahan Makanan (BTM),. Pada makanan jajanan tidak diperbolehkan mengandung rhodaminB.

Bahaya Rhodamin-b bagi tubuh dapat menyebabkan ganguan fungsi hati atau kanker hati. Rhodamin B bisa menumpuk di lemak sehingga lama-lama jumlahnya akan terus bertambah, Rhodamin

Tabel 5. Distribusi Hasil Pemeriksan Rhodamin B

\begin{tabular}{c|l|c|c}
\hline No & \multicolumn{1}{|c|}{ Distribusi } & Frekuensi & Persentase \\
\hline 1 & Positif Rhodamin B & 0 & $00,00 \%$ \\
\hline 2 & Negatif Rhodamin B & 9 & $100 \%$ \\
\hline & Total & 9 & $100 \%$ \\
\hline
\end{tabular}

Sumber : Hasil pemeriksaan LABKESDA Kabupaten Magetan, Tahun 2015

Berdasarkan tabel 5, makanan saus pentol ditinjau dari aspek kimia rhodamin B sampel yang positif 0 dengan persentase $00,00 \%$ dan negatif 9 dengan persentase $100 \%$.

4. Hasil Pemeriksaan Angka Kuman

Kualitas makanan pentol ditinjau dari aspek mikrobiologis: angka kuman.

Pada pemeriksaan, rata-rata jumlah angka kuman: pertama sebesar $683.333 \mathrm{koloni} / \mathrm{gram}$, ke dua sebesar 52.666 koloni/gram, ke tiga sebesar 262.333 koloni/gram, sehingga dilihat dari aspek mikrobiologis angka kuman makanan jajanan pentol tidak memenuhi batas syarat baku mutu
Surat Keputusan Kepala POM RI No. HK.00.06.1.52.4011 Tahun 2009 Tentang Penetapan Batas Cemaran Mikroba dan Kimia Dalam Makanan, yaitu 100.000 koloni/gram. Hasil ini di mungkinkan disebabkan pentol saat dijual dalam keadaan dingin, karena suhu pentol dapat Mempengaruhi pertumbuhan bakteri pada pentol dan penjual menjajakan dipinggir jalan, penjualan dipinggir jalan dapat menyebabkan kontaminasi debu ke pentol sehingga menyebabkan pentol tidak bersih.

Tabel 6. Distribusi Hasil Pemeriksan Angka Kuman

\begin{tabular}{c|l|c|c}
\hline No & \multicolumn{1}{|c|}{ Distribusi } & Frekuensi & Persentase \\
\hline 1 & Angka kuman memenuhi syarat & 4 & $44,44 \%$ \\
\hline 2 & Angka kuman tidak memenuhi syarat & 5 & $55.55 \%$ \\
\hline & Total & 9 & $100 \%$ \\
\hline
\end{tabular}

Sumber: Hasil pemeriksaan laboratorium Prodi D III Kesling Kampus Magetan, Tahun 2015 
Berdasarkan tabel 6, makanan pentol ditinjau dari aspek mikrobiologi yaitu angka kuman, yang memenuhi syarat 4 dengan persentase $44,44 \%$ dan tidak memenuhi syarat 5 dengan persentase $55,55 \%$.

5. Hasil Analisa Pemeriksaan

Organoleptik, Boraks, Formalin,

Rhodamin-B dan Angka Kuman.

Analisa Organoleptik, Boraks,

Formalin, Rhodamin dan Angka

Kuman.
Sampel pentol dari aspek: organoleptik tidak memenuhi syarat, kimia yaitu boraks, formalin dan rhodamin-b sampel memenuhi syarat baku mutu, mikrobiologi angka kuman tidak memenuhi syarat, hasil rata-rata angka kuman pada pentol 332.777 koloni/gram tidak memenuhi batas syarat baku mutu, se hingga pentol tersebut tidak layak untuk dikonsumsi.

Tabel 7. Hasil Analisa Pemeriksaan Organoleptik, Boraks, Formalin, Rhodamin Dan Angka Kuman

\begin{tabular}{c|c|c|c|c|c|c|c|c|c|c}
\hline \multirow{2}{*}{ Sampel } & \multicolumn{10}{c}{ Kategori Kualitas } \\
\cline { 2 - 12 } & Organoleptik & \multicolumn{2}{c}{ Boraks } & \multicolumn{2}{c}{ Formalin } & \multicolumn{2}{c}{ Rhodamin B } & \multicolumn{2}{c}{ A. Kuman } \\
\hline Pentol & MS & TMS & MS & TMS & MS & TMS & MS & TMS & MS & TMS \\
\hline Simpulan & & $\mathrm{x}$ & $\sqrt{ }$ & & $\sqrt{ }$ & & $\sqrt{ }$ & & & $\mathrm{x}$ \\
\hline
\end{tabular}

Sumber: data primer hasil observasi dan pemeriksaan lab. Prodi Kesling Kampus Magetan dan LABKESDA Kab. Magetan, Tahun 2015

Keterangan: TMS $(x)=$ Tidak Memenuhi Syarat. $\quad$ MS $(\sqrt{ })=$ Memenuhi Syarat

Berdasarkan tabel 7, hasil observasi organoleptik secara keseluruhan tidak memenuhi syarat, hasil pemeriksaan laboratorium aspek kimia memenuhi syarat dan hasil mikrobiologi angka kuman tidak memenuhi syarat.

\section{KESIMPULAN}

1. Aspek organoleptik pada makanan pentol warna: putih pucat keabu-abuan, aroma: bau daging dan pati. tekstur: kenyal dan kasar. Rasa: gurih daging dan asin, dinyatakan tidak baik.

2. Kualitas makanan dari aspek kimia.

a. 7 sampel negatif boraks $(77,77 \%)$.

b. 9 sampel negatif formalin (100\%).

c. 9 sampel negatif rhodhamin B $(100 \%)$.

3. Kualitas makanan dari aspek mikrobiologi angka kuman 5 sampel tidak memenuhi syarat (55,55\%).

4. Kualitas makanan pentol dari aspek fisik tidak memenuhi syarat, aspek kimia memenuhi syarat, dan aspek mikrobiologi tidak memenuhi syarat, sehingga pentol tidak layak dikonsumsi.

\section{SARAN}

1. Bagi peneliti lain: perlu diteliti lebih lanjut tentang perilaku penjaja makanan dalam melaksanakan prinsipprinsip hygiene sanitasi makanan.

2. Bagi Pedagang makanan jajanan: sebaiknya lebih memperhatikan prinsipprinsip hygiene sanitasi makanan.

3. Bagi masyarakat terutama para siswa, sebaiknya memahmi cara memilah dan memilih makanan jajanan yang akan dikonsumsi

\section{DAFTAR PUSTAKA}

Anonim. 2011. Bahaya Rhodamin-B. Program Studi D-III Analis Farmasi dan Makanan (ANAFARMA). Pekanbaru Riau: Universitas Abdurrab.

Badan POM RI. 2014. Makanan yang memenuhi persyaratan. Jakarta: Depkes RI.

Dinkes Magetan. 2014. Kasus Keracunan Makanan. Magetan: Dinas Kesehatan Kabupaten Magetan.

Eko Khannedy. 2012. Ciri Bakso Yang Mengandung Borak dan Formalin.http://miembot.wordpress.c om/2012/05/21/ciri-bakso-yangmengandung-boraks-dan-formalin/ diakses: 2 Mei 2012.

Peraturan Kepala Badan Pengawas Obat dan Makanan RI No. HK.00.06.1.52.4011 tentang Penetapan Batas Maksimum Cemaran Mikroba Dan Kimia Dalam Makanan.

Keputusan Menteri Kesehatan Republik Indonesia Nomor 942/Menkes/SK/VII/ 2003 tentang Pedoman Persyaratan Hygiene Sanitasi Makanan Jajanan.

Khannedy Eko. 2012. Ciri Bakso Yang Mengandung Borak dan Formalin. https://miembot.wordpress.com/2012 105/21/ciri-bakso-yang-mengandungborak-dan-formalin/ diakses: 21 Mei 2012 
Mahfuzh. 2014. Memahami Pengertian Formalin Kegunaan dan Bahaya, Formalin.http://www.mystupidtheory .com/2014/10/memahamipengertian-formalin-kegunaan.html. diakses: Januari 2015

Notoadmodjo, Soekijo. 2003. Pendidikan dan Perilaku Kesehatan. Jakarta: Rineka Cipta.

Pamere Nurhidayat. 2012. Ciri-ciri Penggunaan Boraks dan Formalin Pada Pentol dan Bakso. http://pamerepamere.blogspot.com/2012/12/ciriciri-penggunaan boraks-dan.html. diakses: Desember 2012.
Peraturan Pemerintah Nomor 28 Tahun 2004 tentang Keamanan Mutu dan Gizi Pangan.

Peraturan Menteri Kesehatan Republik Indonesia Nomor: 33 Tahun 2012 Tentang Bahan Tambahan Makanan.

Sastroasmoro Sudigdo \& Ismael, S, 2002. Dasar-dasar Metodologi Penelitian Klinis, CV Sagung Seto, Jakarta.

SNI 01-2346-2006 tentang Petunjuk Pengujian Organoleptik dan atau Sensori.

WHO. 2006. Penyakit Bawaan Makanan. Fokus Pendidikan Kesehatan. Jakarta: Penerbit Buku Kedokteran EGC. 